\title{
Pengaruh Perbandingan Terigu Dengan Tepung Kecambah Kacang Merah (Phaseolus vulgaris (L.) Terhadap Karakteristik Pancake
}

\author{
The Effect Comparison Of Wheat Flour With Red Bean Sprout Flour (Phaseolus vulgaris (L.) \\ On The Characteristics Of Pancake
}

\section{Lucky Arisonna Roring*, Ni Wayan Wisaniyasa, I Dewa Gede Mayun Permana}

\author{
Program Studi Ilmu dan Teknologi Pangan, Fakultas Teknologi Pertanian, \\ Universitas Udayana, Jl. Raya Kampus Unud, Jimbaran, Kuta Selatan, Badung-Bali \\ *Email: luckyarisonna29@gmail.com
}

\begin{abstract}
This study was aimed to determine the effect of wheat flour comparison with red bean sprout flour on the characteristics of pancakes and to determine the exact concentration of red bean sprout flour that was able to produce pancakes with the best characteristics. This study used a randomized block design with the ratio of flour and red bean sprouts (100\%: 0\%, 60\%: 40\%, 50\%: 50\%, 40\%: 60\%, 30\%: 70\%), repeated three times to obtain 15 units of experiment. The data obtained were then analyzed by variants and if there was any effect on the treatment, then continued with Duncan test. The variables observed were moisture content, ash content, protein content, fat content, carbohydrate levels, coarse fiber content, and sensory characteristics. The results showed that the addition of red bean sprout effected moisture content, ash content, protein content, fat content, carbohydrate content, crude fiber content, colour, aroma, taste, texture, and overall acceptance of pancake. The best characteristic of pancake substitution was $50 \%$ wheat flour and $50 \%$ red bean sprout flour that produced moisture content $36.14 \%$, ash content $1.86 \%$, fat content $24.15 \%$, protein content $8.31 \%$, carbohydrate content $29.53 \%$, crude fiber content $16.81 \%$, light brown colour (liked), typical aroma of red beans (liked), soft texture (liked), flavour of red beans (liked), and overall acceptance (liked).
\end{abstract}

Keywords: Wheat flour, red bean sprouts, characteristics, pancakes

\section{PENDAHULUAN}

Pangan merupakan sumber zat gizi yang utama bagi manusia dan harus selalu dipenuhi untuk menunjang pertumbuhan dan perkembangan makhluk hidup.Pangan tidak hanya dijadikan sebagai pemuas rasa lapar namun sebagai sumber utama zat-zat gizi seperti karbohidrat, protein, lemak, mineral, vitamin C, E dan beberapa vitamin lainnya untuk menjaga kesehatan tubuh. Produk-produk olahan pangan selalu berkembang seiring waktu dan kemajuan teknologi yang kian pesat.Salah satu produk olahan pangan tersebut yaitu pancake. Pancake berdasarkan definisi yang baku adalah makanan yang terbuat dari terigu, susu, telur dan bahan tambahan lainnya. Pembuatannya melalui tahap pengadonan dan pemanggangan di atas penggorengan atau pan (Sufi, 1999).Bahan utama dalam pembuatan pancake adalah terigu. Indonesia sampai saat ini masih mengimpor terigu. Terigu merupakan tepung yang berbahan dasar gandum yang diperoleh dengan cara penggilingan (Belizt dan Grosch, 1987).Terigu merupakan bahan pangan impor, sehingga penggunaan terigu perlu dikurangi. Konsumsi terigu saat ini mulai dikurangi sesuai dengan Peraturan Presiden No. 68 Tahun 2002 mengenai ketahanan pangan, yaitu pengembangan penggunaan bahan pangan lokal seperti umbi- 
umbian dan kacang-kacangan (Richana, 2014).Berdasarkan hal tersebut maka perlu diupayakan penggunaan bahan pangan lokal seperti kacang-kacangan salah satunya kacang merah.Salah satu upaya untuk meningkatkan kualitas kacang-kacangan adalah melalui proses perkecambahan, perkacambahan bertujuan untuk mengurangi zat anti gizi yang terkandung dalam kacang merah dan meningkatkan kandungan gizi dari kacang merah seperti protein, vitamin $\mathrm{C}$ dan vitamin E (Wisaniyasa dkk., 2015 dan Wisaniyasa dkk., 2017).

Kecambah kacang merah langsung dapat dilakukan peroses penepungan agar lebih mudah penggunaannya dalam membuat suatu produk. Tepung kecambah kacang merah dapat berfungsi sebagai pengganti terigu karena memiliki kandungan karbohidrat $64,82 \%$ dan protein $17,59 \%$ (Wisaniyasa dan Suter, 2016). Penggunaan tepung kecambah kacang merah dalam pembuatan pancake bertujuan untuk meningkatkan penggunaan bahan lokal dalam pembuatan suatu produk makanan sehingga akan mendukung mengurangi ketergantungan pada terigu. Untuk itu perlu dilakukan penelitian pembuatan pancake dengan memvariasikan perbandingan terigu dengan tepung kecambah kacang merah.

\section{METODE PENELITIAN}

\section{Waktu dan Tempat Penelitian}

Penelitian ini dilaksanakan di Laboratorium Pengolahan Pangan dan Laboratorium Analisis Pangan Fakultas Teknologi Pertanian Universitas
Udayana. Penelitian ini dilakukan pada bulan Mei 2017 - Agustus 2017.

\section{Bahan dan Alat}

Bahan yang digunakan dalam penelitian ini meliputi dua hal yaitu untuk pembuatan produk dan untuk melakukan uji analisis.Bahan yang dipergunakan dalam penelitian ini adalah kacang merah segar, terigu (Segitiga Biru) , margarin (Blue Band), gula (gulaku), telur, baking powder (koepoe-koepoe), vanili (koepoe-koepoe), garam (dolphin). Bahan kimia yang dipergunakan dalam analisis adalah aquades, Heksan (Bratachem), Tablet Khjedhal (Natrium sulfat, Cupri (II) sulfat, Selenium, Pholyetilen Glycol), $\mathrm{HCl}$ (Merck $K G a A), \mathrm{NaOH}$ (Merck KGaA), $\mathrm{H}_{2} \mathrm{SO}_{4}$, Asam Borat, indikator phenolphthalein (PP), alkohol (Bratachem).

Alat yang digunakan dalam penelitian ini terdiri dari kain, pan atau wajan (Maxim), baskom, keranjang, loyang, blender, mixer, timbangan, pisau, oven (Memmert), timbangan analitik (Shimadzu), kertas saring Whatman 42, labu takar (Pyrex), erlenmeyer (Pyrex), tabung reaksi (Pyrex), gelas ukur (Pyrex), pipet volume (Pyrex), cawan porslin, muffle, kompor listrik, desikator, destilasi.

\section{Rancangan Percobaan}

Penelitian ini dilaksanakan dengan menggunakan Rancangan Acak Kelompok (RAK), dengan perlakuan perbandingan terigu dengan tepung kecambah kacang merah yang digunakan pada pembuatan pancake, yaitu: $\mathrm{P} 0=$ Terigu $100 \%$ :Tepung Kecambah Kacang Merah 0\%; P1 = Terigu 60\% : Tepung Kecambah Kacang Merah 
40\%; $\mathrm{P} 2=$ Terigu 50\% : Tepung Kecambah Kacang Merah 50\%; P3 = Terigu 40\% : Tepung Kecambah Kacang Merah 60\%; P4 = Terigu 30\% : Tepung Kecambah Kacang Merah 70\%

Masing-masing perlakuan diulang sebanyak 3 kali sehingga diperoleh 15 unit percobaan. Data yang diperoleh dari hasil penilitian dianalisis dengan sidik ragam (ANOVA) dan apabila terdapat pengaruh antar perlakuan maka dilanjutkan dengan uji Duncan's Multiple Range Test (DMRT) (Gomez dan Gomez, 1995). Perlakuan terbaik diperoleh dari uji kimia dan sifat sensori pancake.

\section{Pelaksanaan penelitian}

\section{Pembuatan kecambah kacang merah}

Pembuatan kecambah kacang merah segar disortasi terlebih dahulu kemudian dicuci dengan air mengalir, lalu ditiriskan, setelah ditiriskan kacang merah segar diletakkan di keranjang plastik yang telah diberi alas dan tutup daun pisang, kemudian diperciki air sebanyak $10 \mathrm{ml}$ per 500g kacang merah setiap 12 jam, lalu kacang merah dikecambahkan selama 48 jam ini bertujuan untuk memperoleh hasil kecambah kacang merah dengan kualitas terbaik (Wisaniyasa dkk., 2015).

\section{Pembuatan tepung kecambah kacang merah}

Tahapan selanjutnya setelah perkecambahan 48 jam, kecambah kacang merah dicuci, ditiriskan, lalu dipotong-potong. Kecambah kacang merah yang telah dipotong-potong diletakkan di atas loyang kemudian dioven pada suhu $50^{\circ} \mathrm{C}$ selama 6 jam, setelah kering kecambah kacang merah dihaluskan dengan blender dan diayak dengan ayakan 60 mesh sehingga menjadi tepung (Wisaniyasa dkk., 2015 dan Wisaniyasa dkk., 2017).

\section{Pembuatan pancake perbandingan terigu dengan tepung kecambah kacang merah}

Pembuatan pancake tepung kecambah kacang merah menggunakan bahan-bahan seperti terigu protein sedang, tepung kecambah kacang merah, margarin, gula, telur, baking powder dan susu. Formula pembuatan pancake tepung kecambah kacang merah dapat dilihat pada Tabel 1.

Margarin dicairkan di atas wajan kemudian didingin. Kemudian terigu, tepung kecambah kacang merah, gula, baking powder dan susu. Semua bahan dicampur menjadi satu dan terakhir adonan dicampur dengan mentega cair, selanjutnya adonan dipanggang di atas pan dengan api sedang selama 4 menit.

Tabel 1. Formula pembuatan pancake terigu dan tepung kecambah kacang merah

\begin{tabular}{llllll}
\hline \multicolumn{1}{c}{ Bahan } & P0 & P1 & P2 & P3 & P4 \\
\hline Terigu \% & 100 & 60 & 50 & 40 & 30 \\
Tepung Kecambah Kacang Merah \% & 0 & 40 & 50 & 60 & 70 \\
Gula \% & 50 & 50 & 50 & 50 & 50 \\
Telur \% & 150 & 150 & 150 & 150 & 150 \\
Susu \% & 50 & 50 & 50 & 50 & 50 \\
Baking Powder \% & 20 & 20 & 20 & 20 & 20 \\
Margarin \% & 50 & 50 & 50 & 50 & 50 \\
\hline
\end{tabular}

Keterangan : persentase (\%) di atas berdasarkan jumlah terigu dan tepung kecambah kacang merah 


\section{Variabel yang Diamati}

Variabel yang diamati yaitu kadar air dengan menggunakan metode oven (Sudarmadji, dkk, 1997), kadar abu ditentukan dengan metode pemijaran (Sudarmadji, dkk, 1997), kadar protein menggunakan metode makro-Kjeldahl (Sudarmadji, dkk, 1997), kadar lemakditentukan dengan metode ekstraksi soxhlet(Sudarmadji, dkk, 1997), kadar karbohidrat ditentukan dengan metode by different (Sudarmadji, dkk, 1997), kadar serat kasar berdasarkan metode asam basa
(Sudarmadji, dkk, 1997), dan evaluasi sensoris dengan menggunakkan metode uji hedonik dan uji skoring (Soekarto, 1985).

\section{HASIL DAN PEMBAHASAN}

\section{Hasil Analisis Proksimat dan Serat Kasar Terigu, Tepung Kacang Merah dan Tepung Kecambah Kacang Merah}

Hasil analisis proksimat dan kadar serat kasar terigu, tepung kacang merah dan tepung kecambah kacang merah dapat dilihat pada Tabel 2 .

Tabel 2. Nilai rata-rata kadar air, kadar abu, kadar lemak, kadar protein, kadarkarbohidrat dan kadar serat kasar terigu, tepung kacang merah dan tepung kecambah kacang merah

\begin{tabular}{|c|c|c|c|c|c|c|}
\hline \multirow[b]{2}{*}{ Jenis Bahan } & \multicolumn{6}{|c|}{ Nilai Rata - Rata } \\
\hline & $\begin{array}{l}\text { Kadar air } \\
\text { (\%bb) }\end{array}$ & $\begin{array}{c}\text { Kadar abu } \\
\text { (\%bb) }\end{array}$ & $\begin{array}{c}\text { Kadar lemak } \\
(\% \text { bb })\end{array}$ & $\begin{array}{l}\text { Kadar } \\
\text { protein } \\
(\% \text { bb })\end{array}$ & $\begin{array}{c}\text { Kadar } \\
\text { karbohidrat } \\
(\% \text { bb })\end{array}$ & $\begin{array}{c}\text { Kadar serat } \\
\text { kasar } \\
\text { (\%bb) }\end{array}$ \\
\hline Terigu & $6,07 \pm 0,09$ & $0,59 \pm 0,02$ & $8,96 \pm 0,66$ & $8,63 \pm 0,59$ & $75,72 \pm 1,37$ & $5,32 \pm 0,39$ \\
\hline $\begin{array}{l}\text { Tepung Kacang } \\
\text { Merah }\end{array}$ & $6,67 \pm 0,16$ & $5,52 \pm 0,27$ & $13,22 \pm 0,48$ & $12,43 \pm 0,55$ & $62,15 \pm 0,17$ & $9,24 \pm 0,04$ \\
\hline $\begin{array}{l}\text { Tepung } \\
\text { Kecambah } \\
\text { Kacang Merah }\end{array}$ & $6,38 \pm 0,00$ & $4,28 \pm 0,00$ & $8,12 \pm 0,59$ & $17,01 \pm 0,84$ & $64,19 \pm 1,43$ & $11,91 \pm 0,64$ \\
\hline
\end{tabular}

Sumber : Nadya (2016)

Tabel 2. menunjukkan bahwa kadar air tepung kacang merah lebih tinggi dibandingkan dengan terigu dan tepung kecambah kacang merah. Kadar air tepung kacang merah $6,67 \%$, tepung kecambah kacang merah 6,38\%, sedangkan terigu 6,07\%.Kadar abu pada tepung kacang merah juga lebih tinggi yaitu $5,52 \%$ dibandingkan dengan tepung kecambah kacang merah 4,28\% dan terigu $0,59 \%$. Besarnya kadar abu produk pangan bergantung pada besarnya kandungan mineral bahan yang digunakan.Hasil analisis kadar lemak terigu yaitu sebesar $8,96 \%$ dan tepung kacang merah sebesar 13,22\%, sedangkan tepung kecambah kacang merah sebesar $8,12 \%$. Hal ini disebabkan karena dilakukan proses perkecambahan dimana perkecambahan dapat menurunkan kadar lemak pada kacang merah.

Kadar protein tepung kecambah kacang merah $17,01 \%$, sedangkan terigu $8,63 \%$ dan tepung kacang merah $12,43 \%$.Kadar protein tepung kecambah kacang merah lebih tinggi dibandingkan dengan terigu dan tepung kacang merah kemungkinan disebabkan pada proses perkecambahan terbentuk asam amino yang tidak 
ada sebelumnya. Terbentuknya asam amino baru menyebabkan kadar protein semakin meningkat.Kadar karbohidrat terigu lebih besar dibandingkan dengan tepung kacang merah dan tepung kecambah kacang merah. Kadar karbohidrat terigu $75,72 \%$, sedangkan tepung kecambah kacang merah $64,19 \%$ dan tepung kecambah kacang merah 62,15\%.Kadar serat kasar pada tepung kecambah kacang merah sebesar $11,91 \%$, sedangkan terigu sebesar 5,32\% dan tepung kacang merah sebesar 9,24\%.Analisis kadar serat kasar pada tepung kecambah kacang merah lebih tinggi dibandingkan terigu dan tepung kacang merah. Hal ini disebabkan karena proses perkecambahan mampu meningkatkan kadar serat pada kacang merah.

\section{Kadar Proksimat dan Serat Kasar Pancake perbandingan Tepung Kecambah Kacang Merah}

Hasil penelitian menunjukkan bahwa nilai ratarata variabel yang diamati dengan perlakuan perbandingan terigu dan tepung kecambah kacang merah (Phaseolus vulgaris L.) dapat dilihat pada Tabel 3

Tabel 3. Nilai rata-rata hasil sidik ragam uji proksimat pancake

\begin{tabular}{ccccccc}
\hline $\begin{array}{c}\text { Perlakuan } \\
\text { Terigu:TKKM }\end{array}$ & Kadar Air & Kadar Abu & Kadar Protein & $\begin{array}{c}\text { Kadar } \\
\text { Lemak }\end{array}$ & $\begin{array}{c}\text { Kadar } \\
\text { Karbohidrat }\end{array}$ & $\begin{array}{c}\text { Kadar } \\
\text { Serat Kasar }\end{array}$ \\
\hline P0 (100:0) & $33,34 \mathrm{a}$ & $0,20 \mathrm{a}$ & $7,44 \mathrm{a}$ & $33,09 \mathrm{e}$ & $25,72 \mathrm{a}$ & $8,31 \mathrm{a}$ \\
P1 (60:40) & $34,79 \mathrm{a}$ & $0,78 \mathrm{ab}$ & $8,13 \mathrm{ab}$ & $28,40 \mathrm{~d}$ & $27,89 \mathrm{ab}$ & $15,66 \mathrm{~b}$ \\
P2 (50:50) & $36,14 \mathrm{ab}$ & $1,86 \mathrm{bc}$ & $8,31 \mathrm{ab}$ & $24,15 \mathrm{c}$ & $29,53 \mathrm{~b}$ & $16,81 \mathrm{~b}$ \\
P3 (40:60) & $38,76 \mathrm{~b}$ & $2,77 \mathrm{~cd}$ & $8,88 \mathrm{bc}$ & $20,37 \mathrm{~b}$ & $29,13 \mathrm{~b}$ & $19,64 \mathrm{c}$ \\
P4 (30:70) & $41,70 \mathrm{c}$ & $3,91 \mathrm{~d}$ & $9,49 \mathrm{c}$ & $16,77 \mathrm{a}$ & $28,12 \mathrm{ab}$ & $24,20 \mathrm{~d}$ \\
\hline
\end{tabular}

Keterangan: Nilai rata-rata yang diikuti oleh huruf yang berbeda pada kolom yang sama menunjukkan perbedaan yang sangat nyata $(\mathrm{P}<0,01)$. TKKM : tepung kecambah kacang merah

\section{Kadar Air}

Hasil analisis ragam menunjukkan bahwa perbandingan terigu dan tepung kecambah kacang merah berpengaruh sangat nyata $(\mathrm{P}<0,01)$ terhadap kadar air pancake. Kadar air tepung kecambah kacang merah 6,38\% sedangkan terigu $6,07 \%$. Kadar air dari pancake dengan bahan berupa subtitusi terigu dan tepung kecambah kacang merah berkisar antara 33,34\% - 41,70\%. Kadar air rata-rata pancake tepung kecambah kacang merah tertinggi terdapat pada perlakuan
P4 30 terigu : 70 tepung kecambah kacang merah sebesar $41,70 \%$, terendah terdapat pada perlakuan P1 100 terigu : 0 tepung kecambah kacang merah sebesar 33,34\%.Kadar air pancake tepung kecambah kacang merah dari Tabel 3 terlihat bahwa semakin banyak penggunaan tepung kecambah kacang merah kadar air pancake meningkat. Hal ini disebabkan karena kadar air tepung kecambah kacang merah lebih tinggi dari terigu. 


\section{Kadar Abu}

Hasil analisis ragam menunjukkan bahwa perbandingan terigu dan tepung kecambah kacang merah berpengaruh sangat nyata $(\mathrm{P}<0,01)$ terhadap kadar abu pancake. Kadar abu tepung kecambah kacang merah 4,28\% sedangkan terigu 0,59\%.Kadar abu dari pancake dengan bahan berupa subtitusi terigu dan tepung kecambah kacang merah berkisar antara 0,20\% - 3,91\%. Kadar abu rata-rata pancake tepung kecambah kacang merah tertinggi terdapat pada perlakuan P4 30 terigu :70 tepung kecambah kacang merah sebesar 3,91\%, terendah terdapat pada perlakuan P1 100 terigu : 0 tepung kecambah kacang merah sebesar 0,20\%.Kadar abu pancake tepung kecambah kacang merah dari Tabel 3 terlihat bahwa semakin banyak penggunaan tepung kecambah kacang merah kadar abu pancake meningkat. Hal ini disebabkan karena kadar abu tepung kecambah kacang merah lebih tinggi dari terigu.

\section{Kadar Protein}

Hasil analisis ragam menunjukkan bahwa perbandingan terigu dan tepung kecambah kacang merah berpengaruh sangat nyata $(\mathrm{P}<0,01)$ terhadap kadar protein pancake. Kadar protein tepung kecambah kacang merah 17,01\% sedangkan terigu $8,63 \%$.Kadar protein dari pancake dengan bahan berupa subtitusi terigu dan tepung kecambah kacang merah berkisar antara $7,44 \%$ - 9,49\%. Kadar protein rata-rata pancake tepung kecambah kacang merah tertinggi terdapat pada perlakuan P4 30 terigu : 70 tepung kecambah kacang merah sebesar 9,49\%, terendah terdapat pada perlakuan P1 100 terigu : 0 tepung kecambah kacang merah sebesar 7,44\%.Kadar protein pancake tepung kecambah kacang merah dari Tabel 3 terlihat bahwa semakin banyak penggunaan tepung kecambah kacang merah kadar protein pancake meningkat. Hal ini disebabkan karena kadar protein tepung kecambah kacang merah lebih tinggi dari terigu.

\section{Kadar Lemak}

Hasil analisis ragam menunjukkan bahwa perbandingan terigu dan tepung kecambah kacang merah berpengaruh sangat nyata $(\mathrm{P}<0,01)$ terhadap kadar lemak pancake. Kadar lemak tepung kecambah kacang merah $8,12 \%$ sedangkan terigu $8,96 \%$. Kadar lemak dari pancake dengan bahan berupa subtitusi terigu dan tepung kecambah kacang merah berkisar antara $16,77 \%$ $33,09 \%$. Kadar lemak rata-rata pancake tepung kecambah kacang merah tertinggi terdapat pada perlakuan P0 100 terigu : 0 tepung kecambah kacang merah sebesar 33,09\%, terendah terdapat pada perlakuan P4 30 terigu : 70 tepung kecambah kacang merah sebesar $16,77 \%$.Kadar lemak pancake tepung kecambah kacang merah dari Tabel 3 terlihat bahwa semakin banyak penggunaan tepung kecambah kacang merah kadar lemak pancake meningkat. Hal ini disebabkan karena kadar lemak teriggu lebih tinggi dari teppung kecambah kacang merah.

\section{Kadar Karbohidrat}

Hasil analisis ragam menunjukkan bahwa perbandingan terigu dan tepung kecambah kacang merah berpengaruh sangat nyata $(\mathrm{P}<0,01)$ terhadap kadar karbohidrat pancake. Kadar karbohidrat tepung kecambah kacang merah 
$64,19 \%$ sedangkan terigu $75,72 \%$. Kadar karbohidrat dari pancake dengan bahan berupa subtitusi terigu dan tepung kecambah kacang merah berkisar antara 25,72\% - 29,53\%. Kadar karbohidrat rata-rata pancake tepung kecambah kacang merah tertinggi terdapat pada perlakuan P2 50 terigu :50 tepung kecambah kacang merah sebesar $29,53 \%$, terendah terdapat pada perlakuan P1 100 terigu : 0 tepung kecambah kacang merah sebesar 25,72\%. Perbandingan kadar karbohidrat pancake berdasarkan by different, oleh karena itu hasil yang diperoleh sangat tergantung dari kadar air, kadar abu, kadar lemak, kadar protein pancake.

\section{Serat Kasar}

Hasil analisis ragam menunjukkan bahwa perbandingan terigu dan tepung kecambah kacang merah berpengaruh sangat nyata $(\mathrm{P}<0,01)$ terhadap kadar serat pancake. Kadar serat kasar tepung kecambah kacang merah 11,91\% sedangkan terigu 5,32\%. Kadar serat kasar dari pancake dengan bahan berupa subtitusi terigu dan tepung kecambah kacang merah berkisar antara $8,31 \%-24,20 \%$. Kadar serat kasar rata-rata pancake tepung kecambah kacang merah tertinggi terdapat pada perlakuan P5 30 terigu :70 tepung kecambah kacang merah sebesar 24,20\%, terendah terdapat pada perlakuan P1 100 terigu : 0 tepung kecambah kacang merah sebesar 8,31\%.Kadar serat kasar pancake tepung kecambah kacang merah dari Tabel 3 terlihat bahwa semakin banyak penggunaan tepung kecambah kacang merah kadar serat kasar pancake meningkat. Hal ini disebabkan karena kadar serat kasar tepung kecambah kacang merah lebih tinggi dari terigu.

\section{Sifat Sensoris}

Pengujian evaluasi sensoris dilakukan oleh 15 panelis semi terlatih. Nilai rata-rata penilaian uji sensoris pancake tepung kecambah kacang merah dapat dilihat pada Tabel 4.

\section{Warna}

Hasil analisis ragam perlakuan perbandingan terigu dengan tepung kecambah kacang merah berbeda sangat nyata terhadap warna pancake yang dihasilkan. Nilai rata-rata panelis terhadap warna (hedonik) tertinggi diperoleh P2 dengan perlakuan 50\% terigu dan $50 \%$ tepung kecambah kacang merah yaitu 6,60 (sangat suka), nilai rata-rata terendah diperoleh perlakuan P4 (40\% terigu dan 60\% tepung kecambah kacang merah) yaitu 5,00 (agak suka). Nilai rata-rata panelis terhadap warna (skoring) pancakedapat dilihat pada Tabel 4, tertinggi diperoleh perlakuan P4 (30\% terigu dan $70 \%$ tepung kecambah kacang merah) yaitu 4.33 (coklat tua), sedangkan nilai rata-rata terendah diperoleh perlakuan P1 $100 \%$ terigu dan $0 \%$ tepung kecambah kacang merah yaitu 1,00 (kuning).Warna merupakan parameter fisik yang terbentuk bila cahaya mengenai suatu objek dan dipantulkan mengenai mata. Penilaian warna terhadap suatu pangan sangat penting karena warna merupakan salah satu parameter yang menentukan mutu bahan, dengan perlakuan substitusi tepung kecambah kacang merah akan menghasilkan warna yang berbeda-beda (Muchtadi, Tien R. dan Sugiyono. 1992). 
Tabel 4. Nilai rata-rata uji sensoris pancake tepung kecambah kacang merah

\begin{tabular}{|c|c|c|c|c|c|}
\hline Perlakuan & Warna & Aroma & Rasa & Tekstur & $\begin{array}{l}\text { Penerimaan } \\
\text { Keseluruhan }\end{array}$ \\
\hline $\begin{array}{l}\text { Terigu : } \\
\text { TKKM }\end{array}$ & $\begin{array}{l}\text { Hedonik } \\
\text { Skoring }\end{array}$ & $\begin{array}{l}\text { Hedonik } \\
\text { Skoring }\end{array}$ & $\begin{array}{l}\text { Hedonik } \\
\text { Skoring }\end{array}$ & $\begin{array}{l}\text { Hedonik } \\
\text { Skoring }\end{array}$ & Hedonik \\
\hline P0 (100:0) & $5,20 \mathrm{a} \quad 1,00 \mathrm{a}$ & $5,67 \mathrm{~b} \quad 1,60 \mathrm{a}$ & $5,87 \mathrm{~b} \quad 1,53 \mathrm{a}$ & 5,73 b 4,33 b & $5,47 \mathrm{a}$ \\
\hline P1 (60:40) & $6,40 \mathrm{~b} \quad 2,00 \mathrm{~b}$ & 4,93 a 2,67 a & $6,67 \mathrm{~b} \quad 2,60 \mathrm{~b}$ & $5,60 \mathrm{~b} \quad 3,27 \mathrm{a}$ & $6,40 \mathrm{bc}$ \\
\hline P2 (50:50) & $6,60 \mathrm{~b} \quad 2,60 \mathrm{c}$ & $5,80 \mathrm{~b} \quad 3,73 \mathrm{~b}$ & $6,00 \mathrm{~b} 3,53 \mathrm{c}$ & $6,00 \mathrm{~b} 3,13 \mathrm{a}$ & $6,87 \mathrm{c}$ \\
\hline P3 (40:60) & $6,13 \mathrm{~b} \quad 3,47 \mathrm{~d}$ & 4,53 a $3,53 b$ & 5,07 a 4,13 c & 4,87 a 2,80 a & $6,07 \mathrm{ab}$ \\
\hline P4 (30:70) & 5,00 a $4,33 \mathrm{~d}$ & 5,00 a $4,07 \mathrm{~b}$ & 4,67 a $4,20 \mathrm{c}$ & 4,47 a 3,33 a & $6,27 \mathrm{bc}$ \\
\hline
\end{tabular}

Keterangan: Nilai rata-rata yang diikuti oleh huruf yang berbeda pada kolom yang sama menunjukkan perbedaan yang sangat nyata $(\mathrm{P}<0,01)$. TKKM $=$ tepung kecambah kacang merah.

Skala Hedonik: 1. Sangat tidak suka, 2. Tidak suka, 3. Agak tidak suka, 4. Biasa, 5. Agak suka, 6. Suka, 7. Sangat suka

Skoring warna: 1 . Kuning, 2. Kuning Kecoklatan, 3. Coklat, 4. Coklat Muda, 5. Coklat Tua Skoring aroma dan rasa: 1 . Tidak khas kecambah kacang merah, 2. Kurang khas kecambah kacang merah, 3. Agak khas kecambah kacang merah, 4. Khas kecambah kacang merah, 5. Sangat khas kecambah kacang merah

Skoring tekstur: 1. Sangat Empuk, 2. Empuk, 3. Biasa, 4. Kurang Empuk, 5. Agak Tidak Empuk

\section{Aroma}

Rata-rata nilai kesukaan panelis terhadap aroma (hedonik) pancake dapat dilihat pada Tabel 4, tertinggi diperoleh pada perlakuan P2 50\% terigu dan 50\% tepung kecambah kacang merah yaitu 5,80 (suka), nilai rata-rata terendah diperoleh pada perlakuan P3 40\% terigu dan 60\% tepung kecambah kacang merah yaitu 4,53 (agak suka). Nilai rata-rata (skoring) panelis terhadap aroma pancakedapat dilihat pada Tabel 4, tertinggi diperoleh pada perlakuan P4 30\% terigu dan $70 \%$ tepung kecambah kacang merah yaitu 4.07 (khas kacang merah), sedangkan nilai rata-rata terendah diperoleh pada perlakuan P0 (100\% terigu dan 0\% tepung kecambah kacang merah) yaitu 1,60 (sangat tidak khas kacang merah). Hasil analisis ragam perlakuan substitusi terigu dengan tepung kecambah kacang merah berpengaruh nyata terhadap aroma pancake yang dihasilkan, aroma merupakan salah satu faktor yang digunakan sebagai penentu tingkat kesukaan panelis terhadap suatu produk (Mudjajanto dan Yulianti. 2004).

\section{Rasa}

Hasil analisis ragam perlakuan perbandingan terigu dengan tepung kecambah kacang merah berbeda tidak nyata terhadap rasa pancake yang dihasilkan, rasa merupakan salah satu faktor penentu dalam tingkat penerimaan panelis terhadap suatu produk pangan. Rasa berhubungan dengan komponen bahan yang dapat ditangkap oleh indera perasa seseorang. Hasil analisis menunjukkan rata-rata nilai kesukaan panelis terhadap rasa (hedonik) pancake dapat dilihat pada Tabel 4, tertinggi diperoleh pada perlakuan P2 50\% terigu dan 50\% tepung kecambah kacang merah yaitu 6,00 (sangat suka), nilai rata-rata terendah diperoleh pada perlakuan P4 30\% terigu 
dan $70 \%$ tepung kecambah kacang merah yaitu 4,67 (biasa). Nilai rata-rata (skoring) panelis terhadap rasa pancakedapat dilihat pada Tabel 4, tertinggi diperoleh pada perlakuan $\mathrm{P} 430 \%$ terigu dan $70 \%$ tepung kecambah kacang merah yaitu 4.20 (khas kacang merah), sedangkan nilai ratarata terendah diperoleh pada perlakuan P0 $100 \%$ terigu dan 0\% tepung kecambah kacang merah yaitu 1,53 (sangat tidak khas kacang merah).

\section{Tekstur}

Hasil analisi ragam perlakuan perbandingan terigu dengan tepung kecambah kacang merah berbeda tidak nyata terhadap rasa pancake yang dihasilkan, tekstur merupakan salah satu cara yang dapat digunakan untuk mengetahui tingkat kesukaan konsumen terhadap suatu produk makanan. Faktor yang mempengaruhi tekstur pancake ditentukan oleh bahan-bahan yang digunakan.Tekstur merupakan salah satu cara yang dapat digunakan untuk mengetahui tingkat kesukaan konsumen terhadap suatu produk makanan. Nilai rata-rata tingkat kesukaan panelis terhadap tekstur (hedonik) pancakedapat dilihat pada Tabel 4, tertinggi diperoleh pada perlakuan P2 50\% terigu dan 50\% tepung kecambah kacang merah yaitu 6,00 (suka), nilai rata-rata terendah diperoleh P4 30\% terigu dan $70 \%$ tepung kecambah kacang merah yaitu 4,47 (agak suka). Nilai rata-rata panelis terhadap tekstur (scoring) dapat dilihat pada Tabel 4, tertinggi diperoleh P0 $100 \%$ terigu dan 0\% tepung kecambah kacang merah yaitu 4,33 (empuk), sedangkan nilai ratarata terendah diperoleh pada perlakuan P3 40\% terigu dan $60 \%$ tepung kecambah kacang merah yaitu 2,80 (kurang empuk).

\section{Penerimaan Keseluruhan}

Hasil analisis ragam perlakuan perbandingan terigu dengan tepung kecambah kacang merah berbeda sangat nyata terhadap penerimaan keseluruhan pancake yang dihasilkan, penerimaan keseluruhan terhadap pancake dilihat dari tingkat kesukaan panelis. Penerimaan keseluruhan merupakan faktor yang mencakup warna, rasa, dan aroma sehingga produk dapat diterima oleh panelis. Rata-rata nilai kesukaan panelis terhadap penerimaan keseluruhan (hedonik) dapat dilihat pada Tabel 4, tertinggi diperoleh pada perlakuan P2 50\% terigu dan 50\% tepung kecambah kacang merah dengan rata-rata 6,87. Nilai rata-rata terendah diperoleh pada perlakuan $\mathrm{P} 1 \quad 40 \%$ terigu dan $60 \%$ tepung kecambah kacang merah yaitu 5,47 (agak suka). Penilaian penerimaan keseluruhan panelis dipengaruhi oleh beberapa faktor seperti, warna, aroma, tekstur, dan rasa pada pancake.

\section{KESIMPULAN DAN SARAN}

\section{Kesimpulan}

Berdasarkan hasil penelitian ini, maka dapat disimpulkan beberapa hal sebagai berikut:

1. Perbandingan tepung kecambah kacang merah pada pembuatan pancake sangat berpengaruh terhadap kadar air, kadar abu, kadar protein, kadar lemak, kadar karbohidrat, kadar seratkasar, warna, aroma, tekstur, rasa, dan penerimaan keseluruhan.

2. Penggunaan $50 \%$ terigu dan $50 \%$ tepungkecambah kacangmerah mampu menghasilkan pancake dengan karakteristik terbaik yaitu:kadar air 36,14\%, kadar abu 
$1,86 \%$, kadar protein $8,31 \%$,kadar lemak 24,15\%, kadarkarbohidrat 29,53\%, kadar serat kasar 16,81\%, warna cokelat muda (suka), aroma khaskacang merah (suka), tekstur empuk (suka), rasa khas kacang merah (suka), danpenerimaan keseluruhan (suka).

\section{Saran}

Pembuatan pancake tepung kecambah kacang merah sebaiknya menggunakan $50 \%$ terigu dan $50 \%$ tepung kecambah kacang merah. Perlu adanya penelitian lebih lanjut tentang umur simpan pancake dari hasil substitusi tepung kecambah kacang merah.

\section{DAFTAR PUSTAKA}

Belitz, H.D. dan W. Grosch. 1987. Food Chemistry. $2^{\text {nd }}$ Ed. Springer.

Gomez, K.A. dan A.A. Gomez . 1995. Prosedur Statistik Untuk Penelitian Pertanian. UI Press,Jakarta.

Muchtadi, Tien R. dan Sugiyono. 1992. Ilmu Pengetahuan Bahan Pangan. IPB. Bogor.

Mudjajanto, E. E. dan L. N. Yulianti. 2004. Membuat Aneka Roti. Penerbit Swadaya. Jakarta.

Nadya, Citra Dewantari, I G.A.M. 2016. Pengaruh Substitusi Terigu dengan Tepung Kecambah Kacang Merah (Phaseolus vulgaris L) Terhadap Karakteristik Cookies.
Richana.2014. Keniscayaan Daulat Pangan. Available

from:http://pascapanen.litbang.pertanian.go .id/index.php/id/berita/135

Soekarto, T. T. 1985. Penilaian organoleptik untuk industri pangan dan hasil pertanian,PUSBANGTEPA Food Technology Development Center Institut Pertanian Bogor.

Sudarmadji S, H. Bambang dan Suhardi. 1997. Prosedur Analisa untuk Bahan Makanan danPertanian.Liberty.Yogyakarta.

Sufi, S.Y., 1999. Kreasi Roti. Gramedia Pustaka Utama, Jakarta.

Wisaniyasa, N. W., K. Suter, Y. Marsono, dan I. N. Kencana Putra. 2015. Germination Effect onFunctional Properties and Antitrypsin Activities of Pigeon Pea (Cajanuscajan(L.) Millsp.)Sprout Flour. Journal Food Science and Quality Management.Vol. 43: 79-83.

Wisaniyasa, N.W. dan I. K. Suter., 2016. Kajian Sifat Fungsional Dan Kimia Tepung KecambahKacang Merah (Phaseolus vulgaris (L.) Dan Aplikasinya Menjadi Flakes.SeminarNasional Sain dan Teknologi II., Universitas Udayana.Denpasar.

Wisaniyasa, N.W., A.S. Duniaji, dan A.A.G.N. Anom Jambe. 2017. Studi Daya Cerna Protein,Aktivitas Antioksidan dan Sifat Fungsional Tepung Kecambah KacangMerah (Phaseolusvulgaris (L.) Dalam Rangka Pengembangan Pangan Fungsional. Media Ilmiah Teknologi Pangan (Scientifie Journal of Food Technology). Vol. 4,No.2, 120-126. 